\title{
VENTILATORY FLOW RELATIVE TO INTRABUCCAL AND INTRAOPERCULAR VOLUMES IN THE SERRASALMID FISH Piaractus mesopotamicus DURING NORMOXIA AND EXPOSED TO GRADED HYPOXIA
}

\author{
KALININ, A. L., ${ }^{1}$ SEVERI, W., ${ }^{2}$ GUERRA, C. D. R., ${ }^{3}$ COSTA, M. J. ${ }^{1}$ and RANTIN, F. T. ${ }^{1}$ \\ ${ }^{1}$ Departamento de Ciências Fisiológicas, Universidade Federal de São Carlos, CEP 13565-905, \\ São Carlos, SP, Brazil \\ ${ }^{2}$ Departamento de Pesca, Universidade Federal Rural de Pernambuco, CEP 52171-900, Recife, PE, Brazil \\ ${ }^{3}$ Departamento de Ciencias Biologicas, Universidad Santa Maria La Antigua, Apartado Postal 6-1696, \\ Estafeta El Dorado, Panama 6, Panama \\ Correspondence to: Francisco Tadeu Rantin, Departamento de Ciências Fisiológicas, Universidade Federal \\ de São Carlos, Rodovia Washington Luiz, km 235, C.P. 676, CEP 13565-905, \\ São Carlos, SP, Brazil, email: ftrantin@ power.ufscar.br
}

Received October 21, 1998 - Accepted August 25, 1999 - Distributed May 31, 2000

(With 3 figures)

\begin{abstract}
Ventilation volume $\left(\dot{\mathrm{V}}_{\mathrm{G}}-\mathrm{mlH}_{2} \mathrm{O} \cdot \mathrm{min}^{-1}\right)$, respiratory frequency $\left(\mathrm{f}_{\mathrm{R}}-\right.$ breaths $\left.\cdot \mathrm{min}^{-1}\right)$ and tidal volume $\left(\mathrm{V}_{\mathrm{T}}-\mathrm{mlH}_{2} \mathrm{O} \cdot \mathrm{breath}^{-1}\right)$ were measured in a group of Piaractus mesopotamicus $(650.4 \pm 204.7 \mathrm{~g} ; \mathrm{n}=10)$ during normoxia and in response to graded hypoxia. The $\mathrm{f}_{\mathrm{R}}$ was maintained constant, around 100 breaths $\mathrm{min}^{-1}$, from normoxia until the $\mathrm{O}_{2}$ tension of the inspired water $\left(\mathrm{PiO}_{2}\right)$ of $53 \mathrm{mmHg}$, below which it increased progressively, reaching maximum values $\left(157.6 \pm 6.3\right.$ breaths $\left.\mathrm{min}^{-1}\right)$ at $10 \mathrm{mmHg}$. The $\mathrm{V}_{\mathrm{T}}$ rose from $1.8 \pm 0.1$ to $6.0 \pm 0.5$ and $5.7 \pm 0.4 \mathrm{mlH}_{2} \mathrm{O} \cdot$ breath $^{-1}$ in the $\mathrm{PiO}_{2}$ of 16 and $10 \mathrm{mmHg}$, respectively. The $\dot{\mathrm{V}}_{\mathrm{G}}$ increased from 169.311 .0 (normoxia) to $940.1 \pm 85.6 \mathrm{mlH}_{2} \mathrm{O} \cdot \mathrm{min}^{-1}$ at the $\mathrm{PiO}_{2}$ of 16 $\mathrm{mmHg}$, below which it also tended to decrease. A second group of fish (29 to $1510.0 \mathrm{~g}, \mathrm{n}=34$ ) was used for the evaluation of allometric relationships concerning ventilation and dimensions of the buccal and opercular cavities. At maximum $\dot{\mathrm{V}}_{\mathrm{G}}$, the $\mathrm{V}_{\mathrm{T}}$ corresponded to $93.2 \pm 2.4 \%$ of the buccal volume and 94.9 $2.3 \%$ of the opercular volume, suggesting that the $\dot{\mathrm{V}}_{\mathrm{G}}$ of P. mesopotamicus is limited by the volumes of buccal and opercular cavities in severe hypoxia.
\end{abstract}

Key words: hypoxia, normoxia, ventilatory parameters, buccal and opercular volumes, Piaractus mesopotamicus.

\section{RESUMO}

Fluxo ventilatório relativo aos volumes intrabucal e intraoperculares no serrasalmídeo Piaractus mesopotamicus durante a exposição à normóxia e à hipóxia gradual

Em um grupo de Piaractus mesopotamicus (Wt $=650,4 \pm 204,7 \mathrm{~g}, \mathrm{n}=10$ ) foram determinados a ventilação branquial $\left(\dot{\mathrm{V}}_{\mathrm{G}}-\mathrm{mlH}_{2} \mathrm{O} \cdot \mathrm{min}^{-1}\right)$, a freqüência respiratória $\left(\mathrm{f}_{\mathrm{R}}-\right.$ ciclos respiratórios $\left.\cdot \mathrm{min}^{-1}\right)$ e o volume ventilatório $\left(\mathrm{V}_{\mathrm{T}}-\mathrm{mlH}_{2} \mathrm{O} \cdot\right.$ ciclo respiratório $\left.{ }^{-1}\right)$ em normóxia e em resposta à hipóxia gradual. A $\mathrm{f}_{\mathrm{R}}$ foi mantida constante, em torno de 100 ciclos respiratórios $\cdot \min ^{-1}$, de normóxia até a tensão de $\mathrm{O}_{2}$ da água inspirada $\left(\mathrm{PiO}_{2}\right)$ de $53 \mathrm{mmHg}$, abaixo da qual aumentou progressivamente, atingindo seus valores máximos $\left(157,6 \pm 6,3\right.$ ciclos respiratórios $\left.\cdot \mathrm{min}^{-1}\right)$ em $10 \mathrm{mmHg}$. O V $\mathrm{T}_{\mathrm{T}}$ aumentou de $1,8 \pm 0,1$ para $6,0 \pm 0,5$ e $5,7 \pm 0,4 \mathrm{mlH}_{2} \mathrm{O} \cdot$ ciclo respiratório ${ }^{-1}$ nas $\mathrm{PiO}_{2}$ de 16 e $10 \mathrm{mmHg}$, respectivamente. $\mathrm{A} \dot{\mathrm{V}}_{\mathrm{G}}$ aumentou de 169,3 $\pm 11,0$ (normóxia) para 940,1 $\pm 85,6 \mathrm{mlH}_{2} \mathrm{O} \cdot \mathrm{min}^{-1}$ na $\mathrm{PiO}_{2}$ de $16 \mathrm{mmHg}$, abaixo da qual também tendeu a diminuir. Um segundo grupo de peixes (29 to $1510,0 \mathrm{~g}, \mathrm{n}=34$ ) foi utilizado para a avaliação das relações alométricas entre a ventilação e as dimensões das cavidades bucal e 
operculares. $\mathrm{Na} \dot{\mathrm{V}}_{\mathrm{G}}$ máxima, o $\mathrm{V}_{\mathrm{T}}$ correspondeu a 93,2 $\pm 2,4 \%$ do volume bucal e $94,9 \pm 2,3 \%$ de volume opercular, sugerindo que a $\dot{\mathrm{V}}_{\mathrm{G}}$ de P. mesopotamicus é limitada pelos volumes dessas cavidades durante hipóxia severa.

Palavras-chave: hipóxia, normóxia, parâmetros ventilatórios, volumes bucal e operculares, Piaractus mesopotamicus.

\section{INTRODUCTION}

Respiratory homeostasis in teleosts depends on an oxygen-oriented control of gill ventilation which normally increases during environmental hypoxia (Holeton \& Randall, 1967; Hughes \& Saunders, 1970; Lomholt \& Johansen, 1979; Steffensen et al., 1982; Rantin \& Johansen, 1984; Kalinin et al., 1996). This response is nearly immediate, reflecting the action of $\mathrm{O}_{2}$ chemoreceptors (Satchell, 1991; Milsom, 1993). The exact sites of these receptors have been considerably discussed and the early literature is not entirely consistent. Branchial receptors were well documented by Milsom \& Brill (1986) and these appear to screen both water and arterial blood.

In many fish species the ventilatory responses to hypoxia are considerable and maintain the arterial $\mathrm{PO}_{2}$ relatively constant during moderate hypoxia (for a review see Milsom, 1993). To attenuate the effects of hypoxia, different species adopt distinct strategies to increase gill ventilation by enhancing tidal volume and/or respiratory frequency.

The relationship between differential pressure of the ventilatory apparatus and the water volume pumped across the gills is determined by the morphology of buccal and opercular chambers and the performance of the ventilatory muscles (Ballintijn, 1969a,b, 1972). These morphological features are species-specific, but may change with development in the individual. Moreover, short term adaptations to the environment may modify the morphology of the chambers (Hughes \& Saunders, 1970).

The respiratory physiology in relation to the environment of the teleost fish depends on the mechanisms described above. Rantin et al. (1992) and Kalinin et al. (1996) studied the respiratory responses to hypoxia in two ecologically distinct water-breathing erythryinids, Hoplias malabaricus, typical of stagnant oxygen poor environments of tropical and sub-tropical regions of South America, and Hoplias lacerdae, that inhabits well-oxygenated rivers of central and southern regions of Brazil.

Both species substantially increased ventilation in response to hypoxia. As a difference, $H$. malabaricus mainly increased tidal volume whereas respiratory frequency changed little. Conversely, $H$. lacerdae predominantly increased ventilation by means of respiratory frequency.

In this context, we studied the serrasalmid fish Piaractus mesopotamicus (Holmberg), known in Brazil as pacu, a migratory species distributed in South America from the Amazon, in the north, to the Paraná-Paraguay basin, in the south (Severi, 1991). This species is an important food fish and highly suitable for aquaculture (Saint-Paul, 1986). Within the Central Brazilian Pantanal, pacu also occurs in shallow waters and in floodplain lakes that are often subjected to temporary hypoxia or even anoxia.

The aim of this study was to assess ventilation volume $\left(\dot{\mathrm{V}}_{\mathrm{G}}-\mathrm{mlH}_{2} \mathrm{O} \cdot \mathrm{min}^{-1}\right)$, respiratory frequency $\left(\mathrm{f}_{\mathrm{R}}-\right.$ breaths $\left.\cdot \mathrm{min}^{-1}\right)$ and tidal volume $\left(\mathrm{V}_{\mathrm{T}}-\mathrm{mlH}_{2} \mathrm{O} \cdot\right.$ breath $\left.^{-1}\right)$ of Piaractus mesopotamicus. In addition, tidal volume was evaluated in relation to the intraopercular and intrabuccal volumes, which allows quantification of the morphological limits to increase of tidal volume.

\section{MATERIAL AND METHODS}

Specimens of Piaractus mesopotamicus $(\mathrm{n}=$ $10 ; \mathrm{Wt}=650.4 \pm 204.7 \mathrm{~g}$, mean SE) were obtained from the Center of Research in Tropical Fish (CEPTA/ IBAMA) - Pirassununga, SP, Brazil. Fish were acclimated to $25^{\circ} \mathrm{C}$ in $250-1$ holding tanks with continuous flow of dechlorinated and well-aerated water (oxygen water tension $-\mathrm{PwO}_{2}>135 \mathrm{mmHg}$ ) for at least 3 weeks prior to experimentation. The fish were fed with commercial food pellets ad libitum but were fasted for two days prior to experimentation. 
Ventilation volume $\left(\dot{\mathrm{V}}_{\mathrm{G}}\right)$ was measured applying the method of Rantin et al. (1992). Fish were housed in a flow-through respirometer while inlet and outlet water $\mathrm{PO}_{2}\left(\mathrm{PinO}_{2}, \mathrm{PoutO}_{2}\right.$, respectively) were continuously recorded. $\mathrm{PE}$ catheters were inserted into the roof of the mouth as well as through both opercular cleithra to perform continuous measurements of inspired $\left(\mathrm{PiO}_{2}\right)$ and expired $\left(\mathrm{PeO}_{2}\right)$ water $\mathrm{O}_{2}$ tensions. The $\dot{\mathrm{V}}_{\mathrm{G}}$ was calculated according to the equation:

$$
\dot{\mathrm{V}}_{\mathrm{G}}=\dot{\mathrm{V}}_{\mathrm{R}} \cdot\left(\mathrm{PinO}_{2}-\mathrm{PoutO}_{2}\right) /\left(\mathrm{PiO}_{2}-\mathrm{PeO}_{2}\right)
$$

where $\dot{V}_{R}$ represents the flow through the respirometer. All water tensions $\left(\mathrm{PinO}_{2}, \mathrm{PoutO}_{2}\right.$, $\mathrm{PiO}_{2}$ and $\mathrm{PeO}_{2}$ ) were measured simultaneously by siphoning the water through the catheters to $\mathrm{O}_{2}$

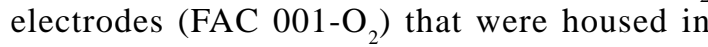
temperature-controlled cuvettes and connected to oxygen analyzers (FAC-204A , FAC - São Carlos, SP, Brazil).

Respiratory frequency $\left(f_{R}\right)$ was recorded connecting the buccal catheter to a pressure transducer (Spectramed P10EZ) that was coupled to a LP-02 amplifier. The resulting signals were displayed on a Linseis 7065 recorder. Ventilatory tidal volume $\left(\mathrm{V}_{\mathrm{T}}\right)$ was calculated by dividing $\dot{\mathrm{V}}_{\mathrm{G}}$ by $f_{R}$.

After surgery the fish were placed into the experimental chamber to recover for 12 hours or more in well-aerated water $\left(\mathrm{PO}_{2}>130 \mathrm{mmHg}\right)$ at $25^{\circ} \mathrm{C}$. Subsequently, $\mathrm{PinO}_{2}$ was stepwise lowered from the normoxic value $(140 \mathrm{mmHg})$ to $100,70,50,40,30$, 20 and $10 \mathrm{mmHg}$ by bubbling the water with $\mathrm{N}_{2}$ or compressed air at controlled rates. Each tension was maintained for a $40 \mathrm{~min}$. period, and the measurements were taken over the last $10 \mathrm{~min}$.

The buccal and opercular volumes were determined according to the method of Kalinin (1996). The buccal and opercular cavities of anaesthetized fish (benzocaine $0.1 \%$ ) were completely filled with an alginate (JelPrint Dentsply Ind. Com. Ltd. Brazil). After hardening, a precision eletronic scale (Micronal B-360) was used to weight the casts. The corresponding volumes were derived from a calibration curve of volume $(\mathrm{ml})$ versus weight $(\mathrm{g})$. The morphometric characteristics of buccal (VBuc) and opercular (VOp) volumes were plotted against total lenght $(\mathrm{Lt}-\mathrm{cm})$ and compared to the plots of weight $(\mathrm{Wt}-\mathrm{g}$ ) versus $\mathrm{Lt}$ for 34 specimens of $P$. mesopotamicus (29 to $1,510 \mathrm{~g}$ ).

\section{Statistical analyses}

One-way analysis of variance (ANOVA) followed by Bartlett's test for homogeneity of variances and Tukey-Kramer multiple comparisons test were employed to evaluate the data. Additionally, the Mann-Whitney test was employed to compare tidal volume in percentage of buccal and opercular volumes.

\section{RESULTS}

Changes in $\dot{\mathrm{V}}_{\mathrm{G}}, \mathrm{f}_{\mathrm{R},}$ and $\mathrm{V}_{\mathrm{T}}$ of P. mesopotamicus during progressive hypoxia are presented in Fig. 1 (upper, middle and lower panel, respectively). The $\dot{\mathrm{V}}_{\mathrm{G}}$ increased by about 5.6-fold with the reduction of $\mathrm{PiO}_{2}$ from normoxia to $16 \mathrm{mmHg}$. This was accomplished by a 3.3-fold increase in $\mathrm{V}_{\mathrm{T}}$ and a 1.6-fold increase in $f_{R}$. The $f_{R}$ increased progressively until the $\mathrm{PiO}_{2}$ of $10 \mathrm{mmHg}$ was reached, while the $\dot{\mathrm{V}}_{\mathrm{G}}$ and $\mathrm{V}_{\mathrm{T}}$ tended to decrease below 16 mmHg.

The Fig. 2 compiles the data for the intrabuccal and intraopercular volumes in relation to body length. This figure also include the length-weight relationships. Combining the data for tidal volume (Fig. 1) and the morphometric information (Fig. 2) it becomes possible to express ventilatory responses in terms of percentage of the maximum volume possible (Fig. 3). When gill ventilation reached a maximum, $\mathrm{V}_{\mathrm{T}}$ corresponded to $93.2 \pm 2.4 \%$ of the buccal volume and $94.9 \pm 2.3 \%$ of opercular volume.

\section{DISCUSSION}

The results obtained in the present study are in agreement with those reported by Kalinin et al. (1996) to the erythrinid H. malabaricus, which maintained a larger $\mathrm{V}_{T}$ whereas $\mathrm{f}_{\mathrm{R}}$ changed little. The responses of $P$. mesopotamicus and H. malabaricus seems advantageous in terms of energy expenditure, assuming that a constant velocity of muscular contraction is energy saving, whereas a higher frequency of contraction occurs on the cost of work against a high internal viscosity of the muscle and of the water (Rantin et al., 1992). 


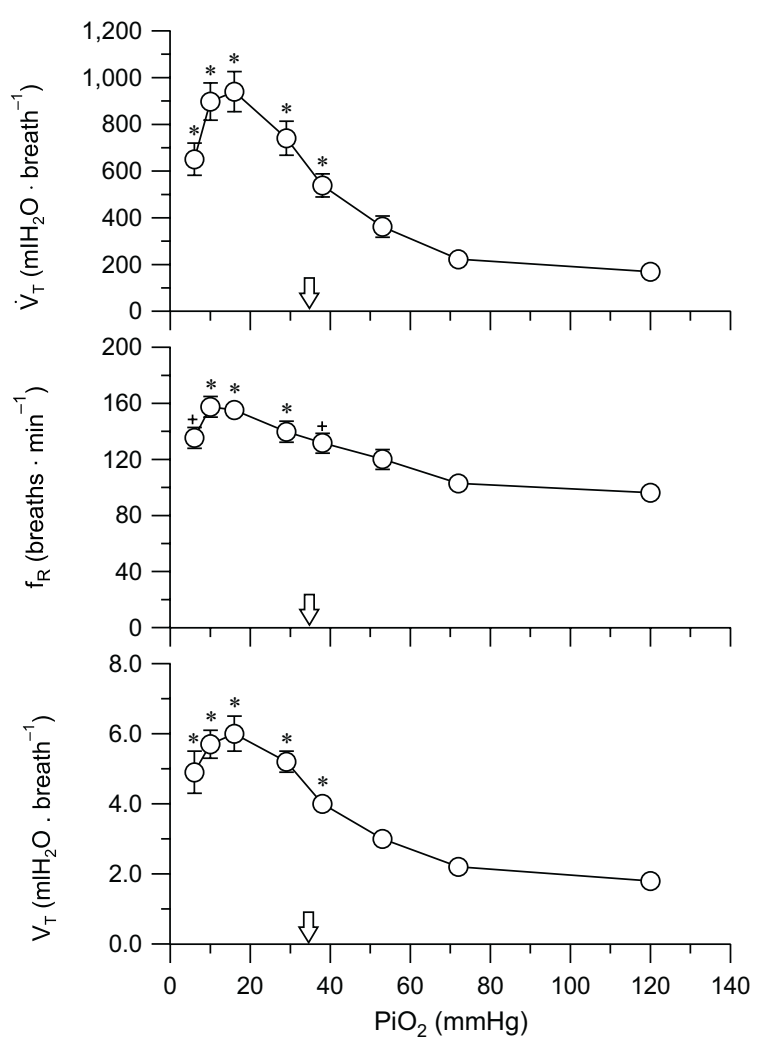

Fig. 1 - Ventilatory variables of Piaractus mesopotamicus: Upper panel: Gill ventilation. Middle panel: Respiratory frequency. Lower panel: Tidal volume. Mean values \pm SE, $n=10$. Significance levels are indicated as follow: $*-p<$ $0.001,+-\mathrm{p}<0.01$. Arrows indicate the critical oxygen tension $\left(\mathrm{PcO}_{2}\right)$ of the species.

Hughes \& Saunders (1970) and Smith \& Jones (1982) reported that trout (Oncorhynchus mykiss) mainly increases ventilation by adjustments of $\mathrm{V}_{\mathrm{T}}$. In trout only the highest levels of $\dot{V}_{\mathrm{G}}$ correlate with any substantial elevation of $f_{R}$. The relative importance of these two components is speciesdependent. As an example, frequency adjustments play a larger role in carp, Cyprinus carpio (Glass et al., 1990). In any event, the studies indicate that ventilatory responses in fish cannot be evaluated without some measurement of tidal volume.

Previous studies (Rantin et al., 1998) have determined the critical oxygen tension $\left(\mathrm{PcO}_{2}\right)$ for P. mesopotamicus as $34 \mathrm{mmHg}$, a high value compared with those presented by typical hypoxiatolerant tropical teleost. It is important to emphasize that, when subjected to environmental hypoxic conditions, this species become dependent on aquatic surface respiration (ASR), when the fish rise to the surface to continue branchial respiration by positioning their mouths to skim the air/water interface which is richer in oxygen due to diffusion from the atmosphere (Saint-Paul \& Bernardino, 1988). This behavior was also observed in experimental conditions by Rantin et al. (1998). These authors observed that the performance of ASR in P. mesopotamicus occurs just below the $\mathrm{PcO}_{2}$ when fish was allowed to access the water surface, compensating the high $\mathrm{PcO}_{2}$ value. In the present study, the highest values of $\mathrm{V}_{\mathrm{G}}, \mathrm{f}_{\mathrm{R}}$ and $\mathrm{V}_{\mathrm{T}}$ occurred below the $\mathrm{PcO}_{2}$ and the inability to increase these parameters in the more hypoxic tensions coincided with the increased time spent in ASR recorded by Rantin et al. (1998).

An evaluation of the ventilatory capacity can be obtained by comparing the tidal volume to the morphometric data for the ventilatory apparatus. The values obtained in the present study show that the maximum responses to hypoxia correlate with $\mathrm{V}_{\mathrm{T}}$ that approach the upper limit set by the morphology of the opercular chamber and this probably explains the lack of any increase in $\mathrm{V}_{\mathrm{T}}$ 

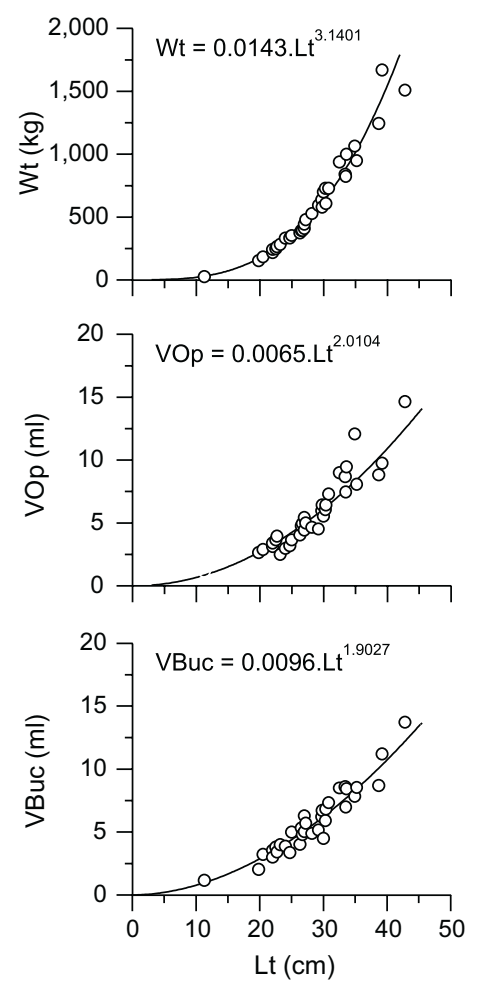

Fig. 2 - The relationships between the total body weight (Wt - upper panel), opercular volume (VOp - middle panel), buccal volume (VBuc - lower panel) and the total body length of Piaractus mesopotamicus $(\mathrm{n}=34)$. Regression equations are shown for the respective figures.

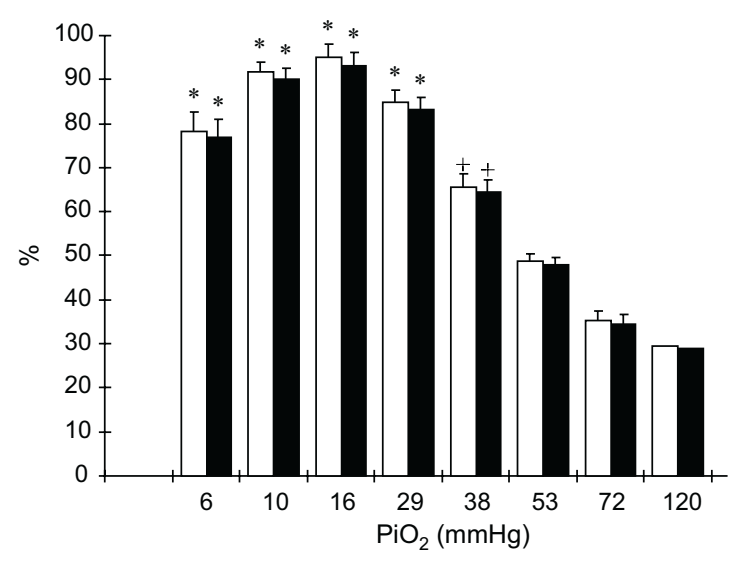

Fig. 3 - Tidal volume in percentage of buccal $(\mathbf{\square})$ and opercular $(\square)$ volumes as a function of oxygen tensions of inspired water in Piaractus mesopotamicus $(\mathrm{n}=10)$. Bars represent mean values \pm SE. Significance levels are indicated as follow: $*-\mathrm{p}<0.001,+-\mathrm{p}<0.01$.

below $16 \mathrm{mmHg}$. The same pattern of response was described by Kalinin et al. (1996) for $H$. lacerdae.
This method for expressing ventilatory responses adds information on the species-specific conditions for responding to hypoxia and on the 
adaptation of the species to environments that may be subjected to temporary or long-terms depletion of dissolved $\mathrm{O}_{2}$. Moreover, the method might explain some responses such as transitions to an increase of respiratory frequency during severe hypoxia.

Acknowledgments - This project was supported by FAPESP (Proc. 95/4654-5) and CNPq (Proc. 300641/86-9 and 400210/94-0). Fellowships were provided to C. D. R. Guerra by CAPES and American States Organization (Proc. 228081-PN) and to M. J. Costa by CAPES. Specimens of pacu were kindly provided by CEPTA/IBAMA, Pirassununga, SP, Brazil. We acknowledge skillful technical assistance from the biologist J. R. Sanches and Mr. N. S. A. Matos.

\section{REFERENCES}

BALLINTIJN, C. M., 1969a, Movement pattern and efficiency of the respiratory pump of the carp (Cyprinus carpio L.). J. Exp. Biol., 50: 593-613.

BALLINTIJN, C. M., 1969b, Muscle co-ordination of the respiratory pump of the carp (Cyprinus carpio L.). $J$. Exp. Biol., 50: 569-591.

BALLINTIJN, C. M., 1972, Efficiency, mechanics and motor control of fish respiration. Respir. Physiol., 14: $125-141$.

GLASS, M. L., ANDERSEN, N. A., KRUHØFFER, M., WILLIAMS, E. M. \& HEISLER, N., 1990, Combined effects of environmental $\mathrm{PO}_{2}$ and temperature on ventilation and blood gases in the carp (Cyprinus carpio L.). J. Exp. Biol., 148: 1-17.

HOLETON, G. F. \& RANDALL, D. J., 1967, The effect of hypoxia upon the partial pressure of gases in the blood and water efferent to the gills of rainbow trout. J. Exp. Biol., 46: 317-327.

HUGHES, G. M. \& SAUNDERS, R. L., 1970, Responses of he respiratory pumps to hypoxia in the rainbow trout (Salmo gairdneri). J. Exp. Biol., 53: 529-545.

KALININ, A. L., 1996, Função respiratória de tilápia do Nilo, Oreochromis niloticus, em diferentes condições de $\mathrm{O}_{2}$ ambiental: Tomada de $\mathrm{O}_{2}$ branquial e cutânea, medidas diretas e determinações indiretas dos parâmetros ventilatórios. $\mathrm{PhD}$ Thesis, Federal University of São Carlos, SP, Brazil.

KALININ, A. L., RANTIN, F. T., FERNANDES, M. N. \& GLASS, M. L., 1996, Ventilatory flow relative to intrabucal and intraopercular volumes in two ecologically distinct erythrinids (Hoplias malabaricus and Hoplias lacerdae) exposed to normoxia and graded hypoxia. Cap. 16, pp. 191-202. In: A. L. Val, V. M. F. Almeida-Val \& D. J. Randall (eds.), Physiology and Biochemistry of Fishes of the Amazon. Manaus, Editora do INPA, 402p.
LOMHOLT, J. P. \& JOHANSEN, K., 1979, Hypoxia acclimation in carp. How it affects $\mathrm{O}_{2}$ uptake, ventilation and $\mathrm{O}_{2}$ extraction from the water. Physiol. Zool., 52: $38-49$.

MILSOM, W. K., 1993, Afferent inputs regulating ventilation in vertebrates. In: J. E. P. W. Bicudo (ed.), The vertebrate gas transport cascade. Adaptations and mode of life, pp. 94-105. CRC Press, Inc., Boca Raton, Florida.

MILSOM, W. K. \& BRILL, R. W., 1986, Oxygen sensitive afferent information arising from the first gill arch of yellowfin tuna. Respir. Physiol., 66: 193-203.

RANTIN, F. T. \& JOHANSEN, K., 1984, Responses of the teleost Hoplias malabaricus to hypoxia. Env. Biol. Fish., 11: 221-228.

RANTIN, F. T., KALININ, A. L., GLASS, M. L. \& FERNANDES, M. N., 1992, Respiratory responses to hypoxia in relation to mode of life of two erythrinid species (Hoplias malabaricus and Hoplias lacerdae). J. Fish. Biol., 41: 805-812.

RANTIN, F. T., GUERRA, C. D. R., KALININ, A. L. \& GLASS, M. L., 1998, The influence of aquatic surface respirtion (ASR) on cardio-respiratory function of the serrasalmid fish Piaractus mesopotamicus. Comp. Biochem. Physiol., 119: 991-997.

SAINT-PAUL, U., 1986, Potential for aquaculture of South American freshwater fishes: a review. Aquaculture, 54: 205-240.

SAINT-PAUL, U. \& BERNARDINO, G., 1988, Behavioral and ecomorphological responses of the neotropical pacu (P. mesopotamicus - Teleostei, Serrasalmidae) to oxygen-deficient waters. Exp. Biol., 48: $19-26$.

SATCHELL, G. H., 1991, Physiology and form of fish circulation. Cambridge University Press, New York.

SEVERI, W., 1991, Aspectos morfométricos e estruturais das brânquias de pacu (P. mesopotamicus - Holmberg, 1887, Osteichthyes, Serrasalmidae). M.Sc. Thesis, Federal University of São Carlos, SP, Brazil.

SMITH, F. M. \& JONES, D. R., 1982, The effect of changes in blood oxygen carrying capacity on ventilation volume in the rainbow trout (Salmo gairdneri). J. Exp. Biol., 97: 325-334.

STEFFENSEN, J. F., LOMHOLT, J. P. \& JOHANSEN, K. 1982, Gill ventilation and $\mathrm{O}_{2}$ extraction during graded hypoxia in two ecologically distinct species of flatfish, the flounder (Platichtys flesus) and the plaice (Pleuronectes platessa). Env. Biol. Fish., 7: 157-163. 